\title{
Studies on the Defense Mechanism of the Body and Neurohumoral Regulation
}

Report I

On the Neurohumoral Influence upon the Phagocytic Function of the White Blood Gell

By

Shigeo Okinaka, Ikuya Kubo, Takeo Kuroyanagi and (冲中重雄) (久保郁載) (畔柳武雄)

\section{Tamao Hayashi}

(林圭雄)

(From the III Medical Clinic of Prof. Dr. S. Okin a ka, School of Medicine, University of Tokyo)

(Received for publication, October 26, 1931)

We have been endeavouring recently to study on the neurohumoral regulatory function upon the defense mechanism of the body.

Since the works done by Cannon and Selye etc. the defense unit of the body has been emphasized to be regulated by the neural or humoral control mechanism in the body.

In this report we are going to report on our research works concerning the control mechanism of the body over the phagocytic and motility function of the white blood cells.

Kubo and Kuroyanagi in our clinic found recently that penicillin, when injected in the human or animal, has, besides well known strong bacteriostatic activity, a marked promoting action to the phagocytosis and motility of white blood cells. Namely, the penicillin-injection to the animal or human in the medical dosis causes a temporary increase of phagocytic and motility function of white cells which reaches the maximum in one to two hours after the injection and returns to the former level in about three hours, as Table $I$ and Fig. 1 show.

Rabbit weighed about $2 \mathrm{~kg}$. was used in this experiment. Phagocytic function for the indianink was estimated by the Sugiyama's formula. 300 units per $\mathrm{kg}$. penicillin was injected subcutaneously.

As the control we injected $0.5 \mathrm{cc}$. per $\mathrm{kg}$. physiological salt solution subcutaneously and estimated the phagocytic function of the white blood cells (pseudoeosinophils) of the rabbit continuously as in the proper experiment. As the Table II shows the phagocytic function showed no significant change during three hours of observation. The motility of the 


\section{TABLE I}

Effect of Penicillin Administration on the Phagocytosis of White Blood Cells in Normal Rabbit

\begin{tabular}{|c|c|c|c|c|c|c|c|c|}
\hline & \multicolumn{5}{|c|}{ Grade of phagocytosis } & \multirow{3}{*}{$\begin{array}{l}\text { Number of } \\
\text { white } \\
\text { cells } \\
\text { examined }\end{array}$} & \multirow{3}{*}{$\begin{array}{l}\text { Average } \\
\text { grade of } \\
\text { phagocy- } \\
\text { tosis }\end{array}$} & \multirow{3}{*}{$\begin{array}{l}\text { Percentage of } \\
\text { average grade of } \\
\text { phagocytosis } \\
\text { (control } 100 \%)\end{array}$} \\
\hline & 0 & 1 & 2 & 3 & 4 & & & \\
\hline & - & \pm & + & H & H & & & \\
\hline Control & 21 & 40 & 23 & 13 & 3 & 100 & 1.37 & $100 \%$ \\
\hline$\frac{1}{2} h$ & 30 & 31 & 26 & 12 & 1 & 100 & 1.23 & 90 \\
\hline $1 \mathrm{~h}$ & 19 & 9 & 30 & 33 & 9 & 100 & 1.48 & 108 \\
\hline $2 \mathrm{~h}$ & 19 & 9 & 30 & 33 & 9 & 100 & 2.04 & 149 \\
\hline $3 h$ & 26 & 38 & 24 & 11 & 1 & 100 & 1.23 & 90 \\
\hline
\end{tabular}

Fig. 1. Graphic demonstration of Table I.

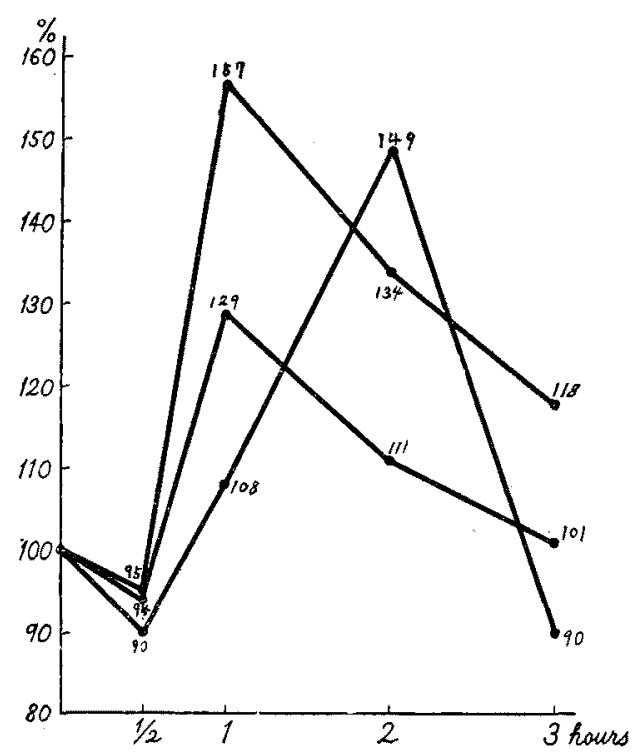

white cells (amoeboid motion) is also measured by Sugiyama's formula. Time of observation 3-4 minutes, number of white cells observed is 20-25 and the blood preparation is examined five times (before the injection, 1, 3,6 and 24 hours after the injection). The difference of the range of physiological motility of individual white cell in the normal rabbit in a day is between 2 and $4 \mu$.

In the vitro experiment, however, the added penicillin to the blood in the test-tube in a same concentration as in the body causes no change in the activity of the white cells. It is also testified that sodium citrate used as an anticoagulant has no effect to the white cell activity. 
TABLE II

Effect of Administration of Physiological Salt Solution on the White Blood Gells in Normal Rabbit (control experiment)

\begin{tabular}{|c|c|c|c|c|c|c|c|c|}
\hline & \multicolumn{5}{|c|}{ Grade of phagocy tosis } & \multirow{3}{*}{$\begin{array}{l}\text { Number of } \\
\text { white } \\
\text { cells } \\
\text { examined }\end{array}$} & \multirow{3}{*}{$\begin{array}{l}\text { Average } \\
\text { grade of } \\
\text { phagocy- } \\
\text { tosis }\end{array}$} & \multirow{3}{*}{$\begin{array}{l}\text { Percentage of } \\
\text { average grade of } \\
\text { phagocytosis } \\
\text { (control 100\%) }\end{array}$} \\
\hline & 0 & 1 & 2 & 3 & 4 & & & \\
\hline & - & \pm & + & $H$ & \# & & & \\
\hline Control & 24 & 35 & 27 & 12 & 12 & 100 & 1.33 & 100 \\
\hline$\frac{1}{2} \mathrm{~h}$ & 23 & 39 & 26 & 11 & 11 & 100 & 1.28 & 96 \\
\hline Ih & 25 & 34 & 26 & 12 & 12 & 100 & 1.34 & 101 \\
\hline $2 \mathrm{~h}$ & 25 & 32 & 27 & 13 & 13 & 100 & $\begin{array}{l}1.37\end{array}$ & 103 \\
\hline $3 \mathrm{~h}$ & 23 & 34 & 26 & 12 & 12 & 100 & 1.32 & 99 \\
\hline
\end{tabular}

Fig. 2. Graphic demonstration of Table II.

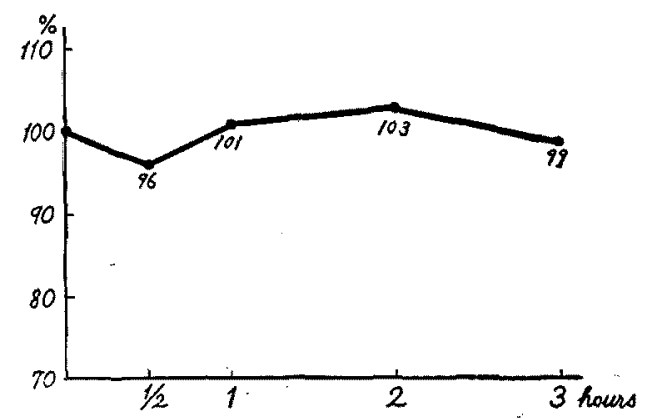

It is clear from these experiments that the penicillin injected to the body has a promoting effect on the white cell activity.

We were interested to know eagerly the mechanism through which the white cell activity was promoted by the penicillin in the body. As a clue to learn that mechanism, we paid attention to the function of carotid sinus body for the present, because it is generally accepted that the carotid sinus body is a strong chemo- and presso-receptors and that the extirpation of the carotid sinus body has a noticeable influence upon the autonomic balance of the body.

We tried to find out whether the extirpation of the carotid sinus body had any influence upon the said penicillin activity to the white blood cell function.

First, we extirpated the carotid sinus bodies of the rabbit and examined thereafter the white cell activity for a certain period without use of penicillin. But we couldn't find any definite change in the white cell function. Then we injected penicillin to the same operated rabbit and examined the white cell activity, comparing with that before the extirpation of the carotid sinus bodies. And we could confirm that the promoting in- 
Fig. 3. Effect of penicillin administration on the phagocytosis of white blood cells before and after (dotted line) the extirpation of carotid sinus bodies. The average grade of phagocytosis is demonstrated as compared with that $(100 \%)$ before penicillin administration.

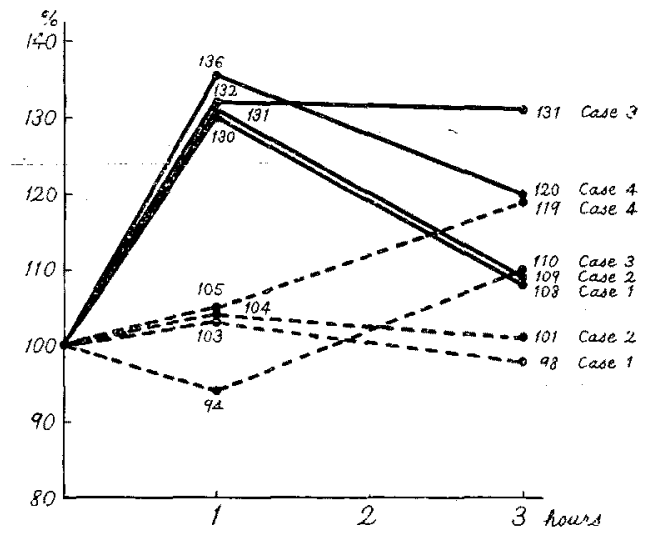

fluence by the penicillin-injection to the white cell activity could no more be found after the carotid sinus body extirpation (Fig. 3).

As one of the possible explanation for this result we can presume that the injected penicillin caused a centripetal impulse through the receptor organ in the carotid sinus body which reflexly activated the white cell function humorally or neurohumorally through some peripheral organs.

Benetato and Hess (1945) published an opinion that the activation of the white cell function which they observed in the stimulation experiment of the hypothalamus seemed to be caused by some activator substances liberated from the spleen. Their view coincides to some extent with ours.

As the mesenchymal defense unit organs we would like to take also liver or spleen etc. into consideration in this mechanism. So as a next step we examined penicillin influence on the white cell function in the patients with disturbed liver functions.

The average phagocytic function of white blood cells in liver patients is not greatly different from that in normal adults. The activation influence of the penicillin on the white cell function is, however, remarkably reduced in the patient with disturbed liver functions (Fig. 4). We also observed that the reduced activation influence by penicillin on the white cell function was increased gradually with the improvement of liver functions by the treatment.

In the experimental liver disturbances of the rabbit caused by $\mathrm{CCl}_{4}$ olive-oil injection we also confirmed that the penicillin activation effect upon the phagocytic function of the white cells was markedly decreased 
Fig. 4. Effect of penicillin administration on the phagocytosis of white blood cells in patients with liver disturbance. The average grade of phagocytosis is demonstrated as compared with that $(100 \%)$ before penicillin administration. Except Case 5 (the grade of liver dysfunction is the slightest) the phagocytic function of white cells is not accelerated.

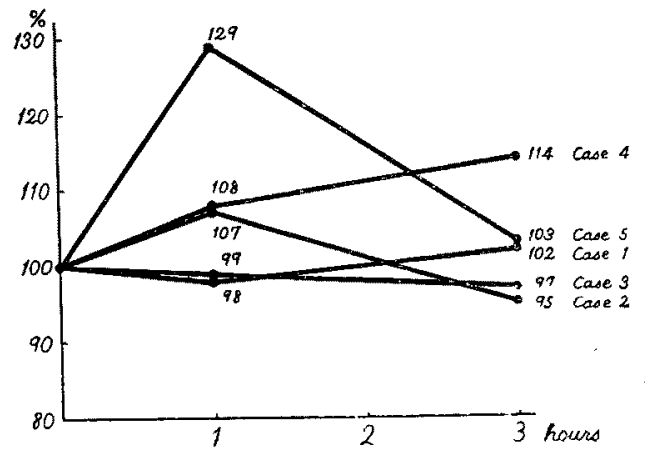

or entirely disappeared (Fig. 5).

It has been clarified from these experiments that the penicillin has, not only its proper bacteristatic activity, a beneficial effect in favour of the body by activating the white cell function. This finding must be bared in mind for physicians in the chemotherapy.

The defense mechanism of the body against various kinds of stresses is of course very complicated and our findings are only a clue to them. We should like to continue our studies further in details from the stand point

Fig. 5. Effect of penicillin administration on the phagocytosis of white blood cells in rabbit with experimental liver disturbance. The average grade of phagocytosis is demonstrated as compared with that $(100 \%)$ before penicillin administration.

ordinary line $\ldots \ldots \ldots \ldots \ldots$ before liver disturbance

dotted line . . . . . . . . . . . . after liver disturbance

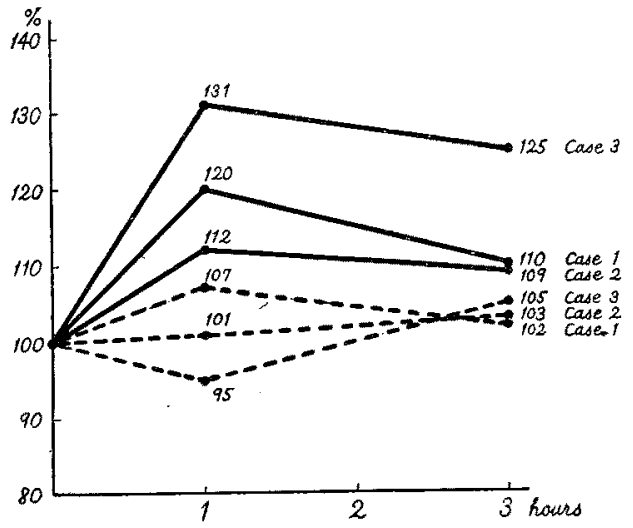


of neuro-humoral system.

\section{SUMMARY}

1. We found that the penicillin injection in the animal and in the human causes a marked activation of white blood cell function (phagocytosis and motility).

2. After the extirpation of the carotid sinus bodies, this penicillin action on the white cell function is markedly reduced or entirely disappeared.

3. In vitro experiment (penicillin and fresh blood are mixed in a test-tube) the above mentioned activation of the white cell function cannot be confirmed.

4. In the patients with marked liver disturbance the activation of white cell function through the penicillin injection is greatly decreased.

5. The activation of the white cell function through penicillin is similarly reduced in the animal with experimental liver disturbance caused by $\mathrm{CCl}_{4}$ olive-oil injection.

6. The activation of white cell phagocytosis and motility seems to be regulated by the neurohumoral mechanism.

\section{References}

1) Hess, W. R.: Helv. Physiol. Pharmacol. Acta, 1943, 1, 32 and 533; 1946, 4, 347, Monatschr. Psych. u. Neurol, 1945, 111, 17.

2) Benetato, von g.: Schweiz. med. Wschr., 1945, 702.

3) Sugiyama, S.: Nisshin Igaku, 1929, 34, 1370; Juzenkai Zasshi, 1928, 33, 639. 